Journal of Health Policy and Management (2019), 4(2): 128-138

https://doi.org/10.26911/thejhpm.2019.04.02.08

\title{
Recognizing Acupuncture Therapist and Services
}

\author{
Chrise Wijanto'), Didik Tamtomo²), Hermanu Joebagyo3) \\ 1)Masters Program in Public Health, Universitas Sebelas Maret \\ 2)Departement of Anatomy, Faculty of Medicine, Universitas Sebelas Maret \\ 3)Faculty of Teaching and Educational Sciences, Universitas Sebelas Maret
}

\begin{abstract}
Background: Acupuncture services in Indonesia keep developing. Law No. 36 of 2014 concerning health personnel has confirmed the status of acupuncture in Indonesia. The regulation includes acupuncture health personnel in the physical therapy group not as traditional ones. However, there are still scientific publications in 2018 which state that acupuncture services are traditional health services. This study aimed to describe the services of acupuncture and acupuncture health personnel.

Subjects and Method: This was a qualitative descriptive one. It was conducted in Surakarta City in November 2018-January 2019. It employed a purposive sampling technique to determine informants. The informants in this study consisted of 5 informants, namely 1 executive board of the Indonesian therapist acupuncture association (HAKTI) center, 1 Central Java HAKTI administrator, 1 Surakarta Ministry of Health Polytechnic lecturer at the Acupuncture Department, and 2 therapists and acupuncture service providers. The data collection in this study was done using the technique of in-depth interviews, observation, and document analysis. The data analysis was conducted using the method of Miles and Huberman.

Results: Acupuncture service is an effort to restore non-pharmacological health using therapy or needle stabbing to help smooth the flow of energy and blood so that the body can be healthier by acupuncturists with a minimum of three diploma education. Minister of Health Regulation No. 34 of 2018 is a special regulation on licensing and the practice of therapist acupuncturists. The purpose of this regulation is to provide a legal protection for health care personnel who are acupuncturists who are about to practice, both practice independently and join health care facilities. This regulation is appropriate because it writes health centers as one of the acupuncture services. receiving acupuncture services, until now the acupuncture service has no definite provisions regarding service fees.
\end{abstract}

Conclusion: Acupuncture service is health recovery efforts using needle puncture techniques. Acupuncture therapists are acupuncturists in the physical ignition group.

Keywords: acupuncture therapist, acupuncture service

\section{Correspondence:}

Chrise Wijanto. Masters Program in Public Health, Universitas Sebelas Maret, Jl. Ir. Sutami 36A, Surakarta 57126, Central Java, Indonesia. Email: chrisewijanto@yahoo.com. Mobile: +6285725873639 .

\begin{tabular}{l}
\hline BACKGROUND \\
\hline Minister of Health Regulation Number \\
038/-BIRHUB/1973 concerning Obligatory \\
List of Acupuncturists is proof that before \\
1980 acupuncture had been in Indonesia. \\
Chinese people in Indonesia are a strong \\
reason for the existence of acupuncture \\
services in Indonesia. According to Saputra \\
and Idayanti (2005) the entry of acupunc-
\end{tabular}

ture in Indonesia is in line with the influx of migrants from China to Indonesia. Acupuncture services in Indonesia are growing even in 2018 the Indonesian Ministry of Health issued Minister of Health Regulation No. 34 of 2018 concerning the Permit and Implementation of Therapist Acupuncture Practice The government's attention to health services for acupuncture is clear and 
time has proven the acceptance of the Indonesian people for acupuncture services.

Law No. 36 of 2014 concerning Health Personnel has confirmed the status of acupuncture in Indonesia. The regulation includes acupuncture health personnel in the physical therapy group not as traditional health personnel. Acupuncture health therapists can be referred to as acupuncture therapists are in a group of physical ignition along with physiotherapy, occupational therapy, and speech therapy. The assumption that the acupuncture service is a traditional health service is still present in the community even until 2018 there are still scientific publications that write acupuncture health services as traditional health services. This is what caused the author to carry out this study, with the aim of describing the therapist's acupuncture and acupuncture services.

\section{SUBJECTS AND METHOD}

\section{Study Design}

This was a qualitative descriptive study. It was conducted in Surakarta, Central Java, from November 2018 to January 2019. The government has one place for acupuncture education in Surakarta.

\section{Informants}

This study employed a purposive sampling technique to determine informants. The informants in this study consisted of 5 informants, namely 1 executive board of the Indonesian therapist acupuncture association (HAKTI) center, 1 Central Java HAKTI administrator, 1 Surakarta Ministry of Health Polytechnic lecturer at the Acupuncture Department, and 2 therapists and acupuncture service providers.

Informants in this study had information that was useful to complete the data. Informants from the central HAKTI management had a big influence in the HAKTI organization, knew the history of HAKTI, and policies regarding the services of acupuncture and therapist acupuncture. Informants from the management of HAKTI in Central Java had a lot of information relating to the services of acupuncture and therapist acupuncture in Surakarta City. The informant from the Surakarta Ministry of Health Polytechnic lecturer at the Acupuncture Department was a figure who received a recommendation from the head of the Surakarta Ministry of Health Polytechnic acupuncture department. Two informants who work as therapists as well as owners of acupuncture services had been practicing acupuncture for more than 3 years and already have employees, and had collaborated with health personnel in addition to acupuncture therapists.

\section{Data Instrument}

The data collection in this study was conducted using in-depth interviews, observation, and study document.

\section{Data Analysis}

The data analysis was performed using the method of Miles and Huberman (1994) including data collection, data reduction, data presentation, and conclusions.

\section{Research Ethics}

This study has obtained ethical clearance. Ethical clearance was obtained from the Research Ethics Committee in Faculty of Medicine, Universitas Sebelas Maret, Surakarta, Central Java, with number 319 / UN 27.6 / KEPK / 2018.

\begin{tabular}{l}
\hline RESULTS \\
\hline 1. Acupuncture services \\
Efforts to restore non pharmacological \\
health use therapy or needle stabbing me- \\
thods to help smooth the flow of energy and \\
blood so that the body becomes healthier by \\
acupuncturists with a minimum of three \\
diploma education. Acupuncture services \\
can be used in promotive, preventive, reha- \\
bilitative and curative health services.
\end{tabular}


Journal of Health Policy and Management (2019), 4(2): 128-138

https://doi.org/10.26911/thejhpm.2019.04.02.08

\section{Regulation of the Minister of Health Number 34 Year 2018}

Minister of Health Regulation No. 34 of 2018 is a special regulation concerning licensing and practice of therapist acupuncturists. This regulation is one proof of the legality of the therapist's health staff. This regulation confirms that acupuncture services can only be done by acupuncture health personnel with a minimum of three years of education. The issuance of this regulation benefits acupuncturists, licensors, and the public. Minister of Health Regulation No. 34 of 2018 makes acupuncture therapists have clear regulations regarding practice permits, through this regulation the licensors both the health office and the integrated licensing office get strong guidelines, and of course this regulation is very helpful in developing acupuncture services that can be utilized by the community.

\section{The purpose of the Minister of Health Regulation Number 34 of 2018}

The aim of the Minister of Health Regulation Number 34 of 2018 is to provide a legal umbrella for acupuncture health personnel who will practice, both independent practice and join other health care facilities. In addition, this regulation clarifies and protects health personnel, the community, and regulates acupuncture service facilities.

\section{Acupuncture therapist health per- sonnel}

Acupuncture health personnel who have practice licenses can be said to be qualified and competent because acupuncture health personnel have graduated from a minimum of three years of education and passed the competency exam, plus seminar and workshop activities to increase their knowledge. However, acupuncture health personnel have a quality that is not maximal, so it needs to be improved and adapted to demand in employment such as hospitals, health centers, clinics, and practice sites for independent acupuncture services.

\section{Acupuncture at the public health center}

The Minister of Health Regulation No. 34 of 2018 stipulates that the public health service as one of the acupuncture services is the right thing because the health center is a service that is close to the community. In addition, with the regulation, it has a clear legal basis for opening acupuncture services. Acupuncture health personnel also have a wider opportunity to work if acupuncture services can be included in health service facilities such as health centers.

\section{Social Acceptance}

The people of Surakarta City have begun to receive acupuncture services. They already believe and feel the benefits. They enthusiastically used acupuncture services during social service activities. However, after the community used the acupuncture service, they experienced confusion to continue the therapy for acupuncture to a hospital or health center because not all hospitals and health centers in Surakarta City had acupuncture service facilities. On the other hand, public interest in utilizing acupuncture services in private acupuncture services has increased.

\section{The cost of acupuncture services}

Acupuncture services do not have definite provisions regarding the cost of services for one therapy. The amount of the fee varies because it is influenced by several things, such as the material used, the location of the acupuncture service, and the policy of the place of service. The cost of an acupuncture service for one therapy can start from IDR 35,000 to IDR 150,000.

\footnotetext{
DISCUSSION

1. Acupuncture services

Acupuncture services are efforts to restore
} 
health without using drugs or known as non-pharmacology (Fan et al., 2019).

Acupuncture services use therapy or needle stabbing methods at the acupuncture point (Imandiri and Yunardi, 2018). Acupuncture services help smooth the flow of energy and blood flow (Oktaria and Fazriesa, 2017). The effects of this therapy are what causes the body to be healthier. Not only can sick people take advantage of acupuncture services, but healthy people can also use acupuncture services to maintain fitness (Abdullah and Yuliana, 2015).

Acupuncture therapists are health personnel who provide acupuncture services. Diploma three (D3) acupuncture is a minimum education qualification that can provide acupuncture services, this is in accordance with Minister of Health Regulation Number 34 of 2018. Regulation of the Minister of Health Number 34 Year 2018 Article 15 paragraph (1) states that "Acupuncture Therapists can carry out professional practice in:

a. Private practice place for acupuncture therapists;

b. Public health center;

c. Clinics; and/or

d. Hospital

Acupuncture therapists can use these rules as a basis for continuing acupuncture services, not only independent practice but also in health care facilities because acupuncture can provide benefits in promotive, preventive, rehabilitative and curative health efforts (Oktaria and Fazriesa, 2017).

Acupuncture services can be used as the efforts of promotive, preventive, rehabilitative, and curative health services, this is in accordance with Minister of Health Regulation No. 34 of 2018 which states that "Acupuncture Services ... for promotive, preventive, symptomatic, rehabilitative and palliative purposes. "Presidential Regula- tion of the Republic of Indonesia Number 72 of 2012 concerning National Health System Article 6 paragraph (1) which states that" The implementation of SKN is emphasized on ..., as well as promotive and preventive efforts without overriding curative and rehabilitative efforts. " from the Indonesian health system.

\section{Minister of Health Regulation Number 34 of 2018}

Minister of Health Regulation No. 34 of 2018 is a special regulation concerning licensing and practice of health personnel for acupuncture therapists. Regulation of the Minister of Health Number 34 of 2018 writes in the section Considering the letter $\mathrm{c}$ "... and to implement the provisions of Article 46 paragraph (7) of Law Number 36 Year 2014 concerning Health Personnel, it is necessary to stipulate a Minister of Health Regulation on the Practice and Practice of Acupuncture Therapists ; "

Law No. 36 of 2014 Article 46 paragraph (1) states that "Every Health Personnel who practices in the field of health services must have a permit." Law Number 36 Year 2014 Article 11 paragraph (10) clearly states that "Type Health personnel included in the group of physical therapy as referred to in paragraph (1) letter i consist of physiotherapists, occupational therapists, speech therapists, and acupuncturists. "

Acupuncture therapists are health personnel and need permission to be able to practice. Regulation of the Minister of Health Number 34 of 2018 concerning Licensing and Implementation of the Practice of Acupuncture Therapists facilitates to be able to practice acupuncture, this is written in the Minister of Health Regulation Number 34 Year 2018 Article 15 paragraph (1) "Acupuncturists can carry out professional:

a. Private practice place for acupuncture 
Journal of Health Policy and Management (2019), 4(2): 128-138

https://doi.org/10.26911/thejhpm.2019.04.02.08

therapists;

b. Public health center;

c. Clinic; and/or

d. Hospital"

The practice of acupuncture is found in Indonesia, there is currently a practice of acupuncture with different education, namely someone who is educated in formal or non-formal acupuncture. Non-formal acupuncture education still exists today, the Ministry of Education (2017) listed 83 acupuncture training and training institutions, this situation seems contradictory when looking at the Minister of Health Regulation Number 34 Year 2018 Article 2 which confirms that the qualifications of health professionals for acupuncture are at least three diploma acupuncture.

Acupuncture therapists do not have clear rules to practice before the Minister of Health Regulation No. 34 of 2018 comes out. The existence of this regulation provides benefits to the community, acupuncturist therapists, as well as licensing parties. Regulation of the Minister of Health Number 34 of 2018 protects the public as parties who get acupuncture services because those who provide acupuncture services must already have permits in accordance with applicable regulations.

Regulation of the Minister of Health No. 34 of 2018 provides acupuncture therapists with clear rules for being able to practice acupuncture. The licensing body has strong guidelines regarding the permits to be issued for acupuncture therapists, namely the license to practice acupuncture therapists (SIPAT).

SIPAT is the name of the permit that is supposed to be currently owned by an acupuncture therapist who will practice in the health field. SIPAT is a permit in accordance with Minister of Health Regulation Number 34 of 2018.
Currently, in Surakarta, there are more than five acupuncture services carried out by health therapists, but not all of them have obtained permits in accordance with Minister of Health Regulation No. 34 of 2018, granting permission other than SIPAT to therapists at this time is not in accordance with regulations which exists. At present, permits are granted to therapist acupuncturists based on Government Regulation Number 103 of 2014 concerning Traditional Health Services or based on Republic of Indonesia Minister of Health Regulation Number 1109 / MENKES / PER / IX / 2007 concerning Implementation of Alternative-Complementary Medicine in Healthcare Facilities of course will conflict with Law Number 36 of 2014 concerning Health Workers. Law No. 36 of 2014 Article 11 paragraph (1) groups health personnel into 13 groups, including physical and traditional health personnel.

Law No. 36 of 2014 states that acupuncture is included in the group of physical immersion workers not in the group of traditional health workers, this is in accordance with the Decree of the Minister of Health of the Republic of Indonesia Number 1277 / MENKES / SK / VIII / 2003 concerning Acupuncturists that are included in the group physical neatness. Thus the acupuncture therapist is a health personnel in the physical ignition group rather than a traditional health peraonnel, so the permit granted is based on the Minister of Health Regulation Number 34 of 2018.

Minister of Health Regulation Number 34 of 2018 is one proof of the legality of the therapist's acupuncture health personnel in addition to Law Number 36 of 2014 concerning Health Workers and Decree of the Minister of Health of the Republic of Indonesia Number 1277 / MENKES / SK / VIII / -2003 concerning Acupuncturists. 


\section{The purpose of the Minister of Health Regulation Number 34 of 2018}

Minister of Health Regulation No. 34 of 2018 aims to provide a legal umbrella for acupuncturists who will practice, both independent practice and join with other health care facilities, this is in accordance with Minister of Health Regulation Number 34 Year 2018 Article 19 letter a "obtaining legal protection as long as carry out its work in accordance with Professional Standards, service standards, and standard operating procedures; "Minister of Health Regulation No. 34 of 2018 is the hope of continuing to develop acupuncture in Indonesia.

Acupuncture is a therapy coming from China.This therapy has spread to various countries around the world including Indonesia. Acupuncture has ben in Indonesia before 1980. Acupuncturists in Indonesia are increasingly developing and need attention from the government. Minister of Health Regulation Number 038 / BIRHUB / -1973 concerning Obligatory Acupuncture List is evidence that the Indonesian Government is paying attention to acupuncture. Acupuncture continued to develop until finally in 1996 acupuncture was able to enter health care facilities based on Minister of Health Regulation Number 1186/MENKES/PER/-XI / 1996 concerning Acupuncture Utilization in Health Service Facilities.

The Minister of Health issued two regulations discussing acupuncture in different ways in 2003. The Decree of the Minister of Health of the Republic of Indonesia Number 1076 / MENKES / SK / VII / 2003 concerning the Implementation of Traditional Medicine Article 3 paragraph (2) letter a "Traditional healers consist of from traditional healers massage massage, fractures, circumcision, birth attendants, reflections, acupressors, acupuncturists, chiropractors and other traditional healers whose methods are similar. "In the same year the Minister of Health issued Decree of the Minister of Health of the Republic of Indonesia Number 1277 / MENKES / SK / VIII / 2003 concerning Acupuncturists write that acupuncturists belong to the group of physical ignition. Acupuncture is included in the traditional medicine group at the beginning of its development in Indonesia, but according to Law Number 36 of 2014 concerning Health Personnel, acupuncturists are health personnel in the physical ignition group.

Minister of Health Regulation No. 34 of 2018 is the foundation for acupuncture therapists to continue to provide acupuncture services for the community with a clear legal protection. In addition, Minister of Health Regulation No. 34 of 2018 protects people who use acupuncture because every acupuncture therapist who will practice acupuncture must have a permit in accordance with existing regulations. From 1980 to 2018 acupuncture continued to develop because the Indonesian people accepted and used acupuncture, they knew that acupuncture could help overcome health complaints and the minimum side effects (Nugraheni and Karsono, 2014).

\section{Acupuncture therapist health per- sonnel}

Acupuncture health personnel who have practice licenses can be said to be qualified and competent because acupuncture health personnel have graduated from a minimum of three years of education and passed the competency exam. Acupuncture health therapists who already have a practice permit can be interpreted that the acupuncture therapist has graduated from formal education either diploma three (D3) or diploma four (D4). This is in accordance with the Regulation of the Minister of Health Number 34 of 2018 Article 2 that 
Journal of Health Policy and Management (2019), 4(2): 128-138

https://doi.org/10.26911/thejhpm.2019.04.02.08

"The lowest qualifications for the education of Acupuncturists are graduates of the Diploma Three Acupuncture program." Acupuncture therapists need to take competency exams to be able to get competency certificates. A competency certificate is a requirement to get an acupuncture therapist registration certificate (STRAT). Regulation of the Minister of Health No. 34 of 2018 Article 3 paragraph (1) states "Every Acupuncture Therapist must have a STRAT to be able to carry out professional practice." After obtaining a STRAT the acupuncturist can process a practice permit.

Practice license is an important foundation for acupuncture therapists to provide acupuncture services. In Surakarta, there is one private acupuncture service center that started its practice since 2015 and continues to grow until this year. This place of service is served by health professionals from acupuncture therapists with diploma three education qualifications (D3). That is, the community has received acupuncture services carried out by acupuncture therapists. Until now, there are at least five private acupuncture services in Surakarta that use acupuncture therapist health personnel.

Acupuncture therapists can continue to improve their abilities by attending seminars or training held by professional organizations and government after graduating from education. This is in accordance with the Regulation of the Minister of Health Number 34 of 2018 Article 20 paragraph (2) which states "Acupuncture Therapists in carrying out their professional practices must always improve service quality by following the development of science and technology through education and training in accordance with their respective fields of work and/or Professional Organizations. "

Acupuncture services in Surakarta will stop if the acupuncture therapist is not qualified and competent. This occurs because the quality is related to the ability to meet community expectations (Miller, 1992), while skills or competencies require other people to judge them. In Surakarta, there was an increase in the number of visits and acupuncture services. This shows that acupuncture therapists are qualified and competent.

The people of Surakarta City have received acupuncture therapists well, but the quality of acupuncture therapists still needs to be improved and adjusted to demand in the workforce. The quality that has not been maximized occurs because the majority of acupuncture majors are not the first choice of prospective new students at the Surakarta Ministry of Health Health Polytechnic, but second and even third. This causes the quality of student input is not optimal. The next problem is that not many alumni work in hospitals or health centers (Haryanto et al., 2016), so that they cannot be used as a reference for role models.

In Surakarta, there are five acupuncture services in private services, one in the hospital, and there are no health centers in Surakarta City that utilize alumni from the acupuncture department of the Surakarta Ministry of Health Health Polytechnic. This situation affects student motivation in learning. These two conditions make the acupuncture therapist's health workers have a quality that is not maximal for performing acupuncture services.

\section{Acupuncture at the public health center}

A public health centers a health facility that promotes promotive and preventive health efforts as well as the spearhead of health services (Napirah et al., 2016). Public health centers and acupuncture services are forms of collaboration in promotive and preventive health efforts. Regulation of the 
Minister of Health of the Republic of Indonesia Number 75 of 2014 Article (1) number (2) states that "... Public health centers are health care facilities that carry out public health efforts and first-degree individual health efforts, with priority over promotive and preventive efforts, to achieve the highest degree of public health ... ".

Promotive and preventive health efforts can use acupuncture services because acupuncture services are useful in these health efforts (Oktaria and Fazriesa, 2017). Acupuncture services can help maintain health and fitness (Abdullah and Yuliana, 2015), while as a preventative effort acupuncture services can help maintain and even lower blood pressure in prehypertensive cases (Liu et al., 2015).

The Minister of Health Regulation No. 34 of 2018 states that acupuncture therapists can perform acupuncture services at the public health centers (Puskesmas), this is appropriate because Puskesmas is a service that is close to the community (Rumengan et al., 2015). In addition, with the regulation, the puskesmas has a clear legal basis for opening acupuncture services. If the Puskesmas will use the basis of Government Regulation Number 103 of 2014 concerning Traditional Health Services and Regulation of the Minister of Health Number 37 of 2017 concerning Traditional Integration Health Services, it will conflict with Law No. 36 of 2014 concerning Health Personnel who clearly say that acupuncture entered into the physical ignition group is not a group of traditional health personnel. Acupuncture health personnel have a wider opportunity to work, not only independent practice but can also be included in health care facilities, namely Puskesmas.

\section{Social Acceptance}

The people in Indonesia have not all known about acupuncture services, but the people of Surakarta City have begun to receive acupuncture services although there are still many people who lack information about it. At least the people of Surakarta City and other regions have received acupuncture services (Hananta et al., 2015). Even people have already felt the benefits (Nugraheni and Karsono, 2014). Acupuncture services are unlikely to last until 2019 in Indonesia if the community does not receive this service. According to Purwanto et al. (2016) in addition to health personnel, service management also affects patient satisfaction. Acupuncture services came to Indonesia before 1980, meaning that more than 39 years of acupuncture services in Indonesia. However, socialization must continue to introduce acupuncture services to the community.

Surakarta people were enthusiastic about using acupuncture services during social service activities, but after utilizing acupuncture services, people experience confusion to continue therapy for acupuncture to hospitals or health centers because not all hospitals and health centers in Surakarta City have acupuncture services. This situation was indeed a problem for the people who want to use acupuncture services at the puskesmas. There were not many acupuncture services in the private sector.

Private acupuncture services that were still limited and the enthusiastm of the people in Surakarta make an opportunity for owners of private acupuncture services to become more aggressive in socializing acupuncture services and improving quality to increase the number of patient visits. There were various ways that can be used to socialize acupuncture services through print media, for example newspapers, magazines, tabloids, even business cards and electronic media, such as radio and television (Wijanto et al., 2019). 
Journal of Health Policy and Management (2019), 4(2): 128-138

https://doi.org/10.26911/thejhpm.2019.04.02.08

\section{The Cost}

Acupuncture services did not have definite provisions regarding the cost of services for one therapy. Professional organizations have not set service rates, so the amount of fees varies because it is influenced by several things, such as the materials used, the location of the acupuncture services, and the policy of the place of service. Surakarta Mayor Regulation Number 24 of 2016 concerning Health Service Rates for Regional Public Service Agencies at the Surakarta City Health Center Technical Implementation Unit writes tariffs for physiotherapy and speech therapy services of IDR 20,000.

Law No. 36 of 2014 states that acupuncture is in the same group as physiotherapy and speech therapy, so it can be assumed that IDR 20,000 is the cost for acupuncture services as well as physiotherapy and speech therapy in a health center. Private acupuncture services certainly have different service costs, ranging from IDR 35,000 to IDR 150 , 000 for the cost of acupuncture services for one therapy.

People who use acupuncture services must remember that acupuncture services cannot immediately solve health problems. This is in accordance with the opinion of Nugraheni and Karsono (2014) that to get a therapeutic effect from acupuncture services requires a regularity and a long process, so that people must consider the overall costs that will be incurred if they will use acupuncture services. According to Munjiah et al. (2015) acupuncture services are cheap health services, although cheap is a relative word and can be different for each person or society.

\section{AUTHOR CONTRIBUTION}

Chrise Wijanto had the idea for the study, collected the data, and wrote the paper.
Didik Tamtomo contributed to develop the idea. Hermanu Joebagyo contributed to design the study and gave suggestion in the discussion.

\section{CONFLICT OF INTEREST}

There is no conflict of interest.

\section{FUNDING AND SPONSORSHIP}

This study used the authors' independent costs.

\section{ACKNOWLEDGEMENT}

We would like to thank to Perhimpunan Akupunktur Terapis Indonesia (HAKTI) and School of Health Sciences Ministry of Health Surakarta for giving permission to collect the data.

\begin{tabular}{l}
\hline REFERENCES \\
\hline Abdullah I, Yuliana P (2015). Tingkat peng- \\
etahuan masyarakat Desa Pakijangan \\
Kecamatan Wonorejo Kabupaten Pa- \\
suruan tentang pengobatan akupunk- \\
tur untuk penyakit lambung (The \\
level of knowledge of the Pakijangan \\
Village community in Wonorejo Dis- \\
trict, Pasuruan Regency about acu- \\
puncture treatment for gastric di- \\
sease). Jurnal Kesehatan Hesti Wira \\
Sakti. Vol 3 (2): 25-30. \\
Fan H, Lu F, Yang A, Dong Y, Liu P, Wang \\
Y (2019). A Review on the nonphar- \\
macological therapy of traditional chi- \\
nese medicine with antihyper-tensive \\
effects.Evidence-Based Complemen- \\
tary and Alternative Medicine. https:- \\
//doi.org/10.1155/2019/1317842.
\end{tabular}

Hananta L, Syukur C, Widjaja NT, Halim F (2015). Pengetahuan, sikap, dan perilaku tentang akupunktur pada pasien rawat jalan Rumah Sakit Atma Jaya (Knowledge, attitudes, and behavior about acupuncture in outpatients at 
Atma Jaya Hospital), Jakarta. Damianus Journal of Medicine. 14(1): 57-66. Haryanto JT, Purwanto, Wahyudi JR (2016). Indikator kinerja pendidikan akupunktur pada Prodi D-III Akupunktur Jurusan Akupunktur Politeknik Kesehatan Kemenkes Surakarta (Indicator of acupuncture edcation performance at the D-III Study Program of the Acupuncture Department of the Surakarta Ministry of Health Polytechnic). Jurnal Ilmu Kesehatan. 5 (1): 86-90.

Imandiri A, Yunardi RT (2018). Gerakan pemeriksaan kesehatan mandiri bagi penduduk lanjut usia melalui pelayanan kesehatan rutin di Surabaya (Independent health screening movement for the elderly through regular health services in Surabaya). Berdikari: Jurnal Pengabdian Masyarakat Indonesia. 1 (2): 60-68. https://doi.org/10.11594/bjpmi.01.02.02.

Ministry of Education and Culture (2017). Laporan akuntabilitas kinerja instansi pemerintah tahun 2017 direktorat pembinaan kursus dan pelatihan (Government agency performance accountability report in 2017 directorate of training and training).

Decree of the Minister of Health of the Republic of Indonesia Number 1076 / MENKES/SK / VII / 2003 concerning Implementation of Traditional Medicine.

Decree of the Minister of Health of the Republic of Indonesia Number 1277 / MENKES/SK/VIII/ 2003 concerning Acupuncturists.

Liu Y, Park J, Shin K, Lee M, Jung H, Kim A, Jung S, et al. (2015). Acupuncture lowers blood pressure in mild hypertension patients : a randomized, controlled, assessorblinded pilot trial. Complementary Therapies in Medi- cine. 23 (5): 658-665. https://doi.org/10.1016/j.ctim.2015.06.014.

Miles MB, Huberman AM (1994). An Expanded sourcebook qualitative data analysis second edition. United States of America: SAGE Publications.

Miller TO (1992). A Customer's definition of quality. Journal of Business Strategy, 13(1): 4-7. https://doi.org/10.1108/eb039461 (February), 4-7.

Munjiah I, Madjid TH, Herman H, Husin F, Akbar IB, Rizal A (2015). Perbedaan pengaruh akupunktur dan vitamin B6 terhadap penurunan intensitas mual muntah pada emesis gravidarum berat (The difference in the effect of acupuncture and vitamin B6 on decreasing the intensity of severe emesis gravidarum). Indonesian Journal of Education And Midwifery Care. 2(2): 1-6. http://dx.doi.org/10.24198/ijemc.v2i2.

Napirah MR, Ryman A, Tony A (2016). Faktor-faktor yang berhubungan dengan pemanfaatan pelayanan kesehatan di wilayah kerja Puskesmas Tambarana Kecamatan Poso Pesisir Utara Kabupaten Poso (Factors related to the utilization of health services in the working area of Tambarana Community Health Center, Poso Pesisir Utara District, Poso District). Jurnal Pengembangan Kota. 4(1): 2939. http://doi:10.14710/jpk.4.1.29-39. Nugraheni AW, Karsono OMF (2014). Alasan pasien non Tionghoa menggunakan pengobatan akupuntur di dua klinik akupuntur Surabaya Selatan (The reasons for non-Chinese patients used acupuncture treatment at two South Surabaya acupuncture clinics). Century. 2(1): 30-43.

Oktaria D, Fazriesa S (2017). Efektivitas akupunktur untuk rehabilitasi stroke (The effectiveness of acupuncture for 
Journal of Health Policy and Management (2019), 4(2): 128-138

https://doi.org/10.26911/thejhpm.2019.04.02.08

stroke rehabilitation). Jurnal Majority. 6(2): 64-71.

Minister of Health Regulation of the Republic of Indonesia Number 038 / BIRHUB/1973 concerning Mandatory Registration of Acupuncturists.

Minister of Health Regulation of the Republic of Indonesia Number 1109 / MENKES/PER-/IX/ 2007 concerning Implementation of Alternative-Complementary Medicine in Health Service Facilities.

Regulation of the Minister of Health of the Republic of Indonesia Number 34 of 2018 concerning Licensing and Implementation of the Practice of Acupuncture Therapists.

Republic of Indonesia Minister of Health Regulation Number 37 of 2017 concerning Traditional Integration Health Services.

Republic of Indonesia Minister of Health Regulation Number 75 of 2014 concerning Public Health Centers.

Regulation of the Minister of Health of the Republic of Indonesia Number 1186 / MENKES/PER/ XI / 1996 concerning Utilization of Acupuncture in Health Service Facilities.

Republic of Indonesia Government Regulation Number 103 of 2014 concerning Traditional Health Services.

Republic of Indonesia Presidential Regulation Number 72 of 2012 concerning the National Health System.

Surakarta Mayor Regulation Number 24 of 2016 concerning Health Service Rates for Regional Public Service Agencies at Surakarta City Health Center Technical Implementation Unit.

Purwanto, Dharmawan R, Demartoto A (2016). Decision to choose acupuncture therapy for degenerative diseases among the elderly at Ja'far Medika Hospital, Karanganyar. Journal of Health Promotion and Behavior. 1(2): 127-137.https://doi.org/10.26911/thejhpb.2016.01.02.08.

Rumengan DSS, Umboh JML, Kandou GD (2015). Faktor-faktor yang berhubungan dengan pemanfaatan pelayanan kesehatan pada peserta BPJS Kesehatan di Puskesmas Paniki Bawah Kecamatan Mapanget Kota Manado (Factors related to the utilization of health services in BPJS Health participants at the PanikiBawah Health Center in Mapanget District, Manado City). Jurnal Ilmu Kesehatan Masyarakat Unsrat. 5(2): 88-100.

Saputra K, Idayanti A (ed) (2005). Akupunktur Indonesia akupunktur dasar (Indonesian acupuncture basic acupuncture). Surabaya: Airlangga University Press.

Law of the Republic of Indonesia Number 36 of 2014 concerning Health Personnel.

Wijanto C, Tamtomo D, Joebagyo H (2019). Promoting acupuncture service in Surakarta, Central Java. Proc. The 5thICPH, February, Indonesia. pp-236. http://doi.org/10.26911/theicph.2019.04.02. 